\title{
Onychomadesis in a 9-month-old boy with hand-foot-mouth disease
}

\author{
Ibrahim Mortada* (D), Rola Mortada and Mohamad Al Bazzal
}

\begin{abstract}
Background: Nail abnormalities in childhood are generally uncommon. Recently, onychomadesis is described as a rare, late complication of hand-foot-mouth disease, which is a viral illness commonly seen in the pediatric age group. It is therefore important to elucidate the presentation of this entity, especially in the context of the handfoot-mouth disease.

Case presentation: We report a case of onychomadesis in a 9-month old Lebanese boy who presented to the emergency department with rapidly progressing nail changes involving all four extremities. These changes appeared few days after the healing of cutaneous lesions of hand-foot-mouth disease.
\end{abstract}

Conclusions: This case highlights the importance of recognizing the association between onychomadesis and handfoot-mouth disease in order to avoid unnecessary treatment and to reassure the patient's parents.

Keywords: HFMD, Onychomadesis, Nail shedding, Infectious diseases, Dermatology

\section{Background}

Onychomadesis, characterized by shedding of nails from the proximal nail beds, is often idiopathic, but can also be linked to certain medications, systemic illnesses, and viral infections including hand-foot-mouth disease (HFMD). HFMD is a common contagious disease, affecting mainly children under the age of 10 , but also reported in adults [1]. This disease is characterized by vesicular rashes on hands, feet, and buttocks and ulcers in the oral mucosa, accompanied by occasional fever [2]. Enterovirus 71 and coxsackievirus A16 are the most common causative agents associated with the condition [3]. Onychomadesis, a rare complication occurring 4 to 6 weeks after the onset of the disease, is usually selflimited and does not require treatment [4]. Common nail abnormalities include leukonychia and Beau lines as well as partial or complete nail shedding [5]. The mechanism of onychomadesis remains to be elucidated, although onychomadesis usually implies that nail matrix proliferation was temporarily inhibited. Bettoli

* Correspondence: ikm03@aub.edu.lb

Independent Consultant, Beirut, Lebanon et al. suggest that periungual inflammation secondary to viral infection may be induced directly by viruses or indirectly by immunocomplexes and consequent distal embolism [6], while Cabrerizo et al. consider that the nail matrix is directly damaged by viral replication, based on the presence of Coxsackie virus 6 in shed nails [7].

In this paper, we describe the presentation of onychomadesis in a boy previously diagnosed with HFMD.

\section{Case presentation}

A 9-month-old boy presented to the emergency department at a tertiary health care center in Beirut in September with a two-day history of nail shedding involving all four extremities. The patient began to have changes in the nails 6 days following the resolution of painful vesicles on the hands, feet, and mouth accompanied by mild fever (temperature $38.3^{\circ} \mathrm{C}$ ), diagnosed as HFMD. The oral blisters had been interfering with feeding; however, the patient did not receive any treatment besides supportive care, leading to the spontaneous resolution of the vesicles. Nail changes began as a greenish-yellowish patch appearing at the 


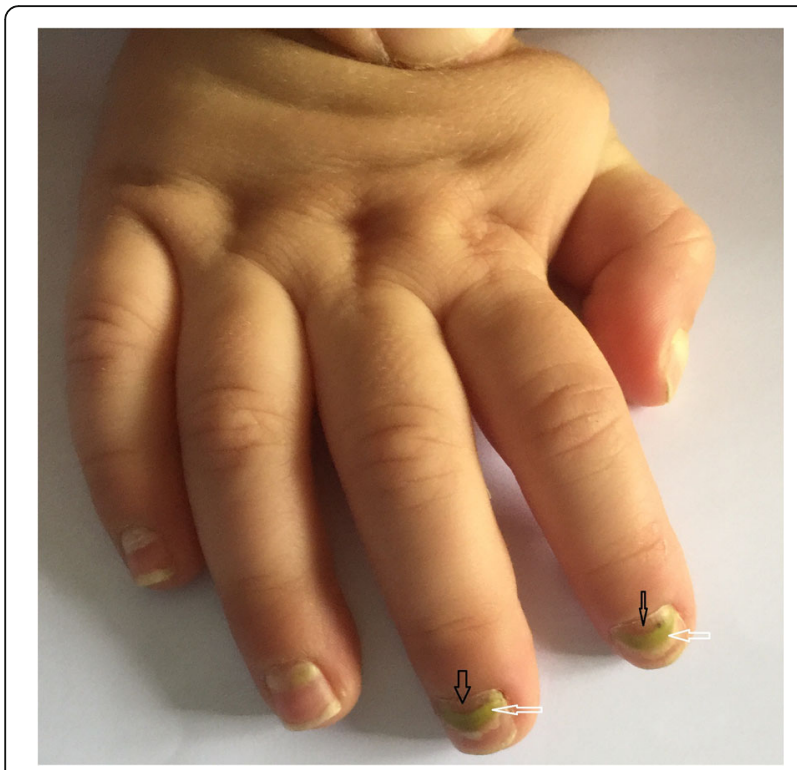

Fig. 1 New nail growth (black arrows) and greenish-yellowish patch (white arrows) in right hand

beginning of the nails and spreading towards the free edge. The nails then started to shed from the lunula towards the free edge concomitantly with the appearance of slowly growing new, pink nails (Fig. 1). Beau lines, horizontal grooves running across the nail plates, were noted (Fig. 2).

\section{Conclusions}

To our knowledge, this is the first case of onychomadesis to be reported from the Middle East. We ought to highlight the importance of recognizing the association between HFMD and onychomadesis in order to avoid unnecessary treatment and to reassure the patient's parents. Nevertheless, it is important to note that this is a rare presentation, and a thorough history and physical exam are necessary to identify the correct etiology and rule out other serious pathologies.

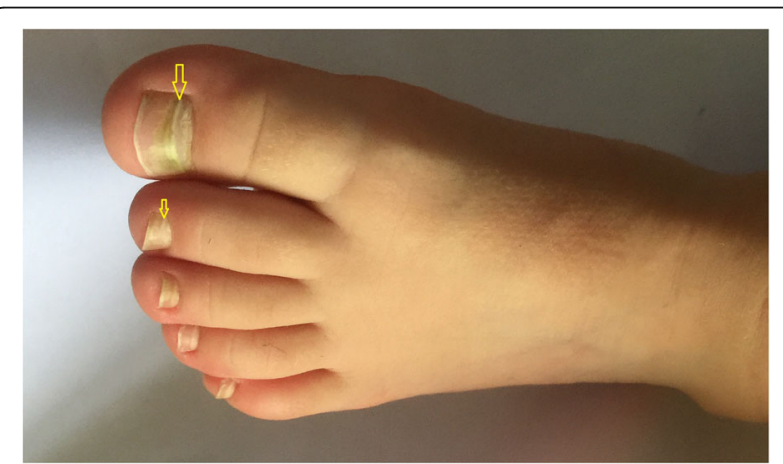

Fig. 2 Beau lines (yellow arrows) in left foot

\section{Funding}

No honorarium, grant, or other form of payment was given to anyone to produce the manuscript.

\section{Authors' contributions}

IM, RM, and MA prepared the literature review. IM was responsible for the manuscript writing, preparation, and submission. All authors read and approved the final manuscript.

\section{Consent for publication}

Written informed consent was obtained from the patient's guardian/parent/ next of kin for the publication of this report and any accompanying images.

\section{Competing interests}

The authors declare that they have no competing interest.

\section{Publisher's Note}

Springer Nature remains neutral with regard to jurisdictional claims in published maps and institutional affiliations.

Received: 2 June 2017 Accepted: 4 August 2017

Published online: 14 August 2017

\section{References}

1. Irving S, Barclay-Buchanan C. Onychomadesis: a rare sequela of hand, foot, and mouth disease. J Emerg Med. 2015;49(4):e127-8.

2. Aswathyraj S, Arunkumar G, Alidjinou EK, Hober D. Hand, foot and mouth disease (HFMD): emerging epidemiology and the need for a vaccine strategy. Med Microbiol Immunol. 2016;205(5):397-407.

3. Yan X, Zhang ZZ, Yang ZH, Zhu CM, Hu YG, Liu QB. Clinical and etiological characteristics of atypical hand-foot-and-mouth disease in children from Chongqing, China: a retrospective study. BioMed Research International. 2015;26:2015.

4. Guimbao J, Rodrigo P, Alberto MJ, Omenaca M. Onychomadesis outbreak linked to hand, foot, and mouth disease, Spain, July 2008. Euro Surveill. 2010;15(37):1

5. Hardin J, Haber RM. Onychomadesis: literature review. British J Dermatol. 2015;172(3):592-6.

6. Bettoli V, Zauli S, Toni G, Virgili A. Onychomadesis following hand, foot, and mouth disease: a case report from Italy and review of the literature. Int J Dermatol. 2013;52(6):728-30.

7. Cabrerizo M, De Miguel T, Armada A, Martinez-Risco R, Pousa A, Trallero G. Onychomadesis after a hand, foot, and mouth disease outbreak in Spain, 2009. Epidemiol Infect. 2010;138(12):1775-8.

\section{Submit your manuscript to a SpringerOpen ${ }^{\circ}$ journal and benefit from:}

- Convenient online submission

- Rigorous peer review

- Open access: articles freely available online

- High visibility within the field

- Retaining the copyright to your article

Submit your next manuscript at $>$ springeropen.com 